\title{
Enhancement of flavor and analyte balance of freeze-dried coconut water
}

\author{
Puran Bridgemohan $^{1 \star}$ and Ronell S. H. Bridgemohan ${ }^{2}$ \\ ${ }^{1}$ Department of Biosciences, Agriculture and Food Technology, University of Trinidad and Tobago. Arima, \\ Trinidad and Tobago. \\ ${ }^{2}$ Waterloo Research Campus, University of Trinidad, Trinidad and Tobago.
}

Received 13 October, 2015; Accepted 25 November, 2015

\begin{abstract}
There is a high incidence of gastro-intestinal and viral diseases after natural disasters, particularly in rural areas in third world countries. Oral rehydration salts (ORS) are used, but there is need for a better tasting substitute which has improved quality, accessibility and storage. Fresh coconut is the preferred choice, but is limited by availability, and rapid nutritional deterioration. Reconstituted powdered products have not retained the natural flavor. The production of a freeze dried ORS was developed using fresh coconut water at different maturity stages. The assessment was done in its pure form and enhanced with natural fruit flavors (mango and passion fruit). Coconut water were frozen $\left(-30^{\circ} \mathrm{C} / 48 \mathrm{~h}\right)$ and vacuum freeze dried (VFD) to produce rehydrated crystals. This was analyzed for its analyte contents, glucose and Brix. The atomic absorption spectrophotometer was used for the mineral analysis. The results indicated that the analytes balance increased with maturity of the coconut fruits, with no differences between the fruit juices. In some mixtures, the electrolyte content was higher in the fruit juices than the coconut water. The study showed improved quality and acceptability through its taste enhancement and extended shelf-life compared to similar ORS.
\end{abstract}

Key words: Analyte electrolyte, freeze-dry, oral re-hydration, flavored coconut water.

\section{INTRODUCTION}

Coconut (Cocos nucifera L.) water or liquid endosperm has many applications such as a growth supplements in plant tissue culture due to its unique chemical composition of sugars, vitamins, minerals, amino acids and phytohormones (Yong et al., 2009; Damcevskie et al., 2014).These phytohormones include indole-3-acetic acid (IAA), indole-3-butyric acid (IBA), abscisic acid (ABA), gibberellic acid (GA), zeatin (Z) and $N^{6}$ - benzyladenine (BA which are present in young coconut water (Ma et al., 2008).

Coconut water is an isonomic beverage with a caloric value of $17.5 \%$ (Khan et al., 2003) and similar electrolytic content to that of the human blood system (Prakash and Mohammed, 2008). It is used in blood pressure, stroke and urinary tract infection management; (Boonumma et al, 2014); and intravenous hydration and resuscitation

*Corresponding author. E-mail: gdramane@gmail.com. Tel: +22994435555.

Author(s) agree that this article remain permanently open access under the terms of the Creative Commons Attribution License 4.0 International License 
Table 1. Description of samples weight before freezing $(\mathrm{g} / 250 \mathrm{ml})$ and vaccum freeze dried (VFD) crystal yield $(\mathrm{g} / 100 \mathrm{ml})$ used in the preparation of the rehydration salts.

\begin{tabular}{llcc}
\hline Treatment code & Treatment description & Weight $\mathbf{( g / 2 5 0 ~} \mathbf{~ m l})$ & VFD crystal $\mathbf{( g / 1 0 0 ~} \mathbf{~ m l})$ \\
\hline EYC & Extra young coconut (water only) & 7.94 & 3.18 \\
SJ/W & Young coconut (water only) & 12.85 & 5.14 \\
SJ/WJ & Young coconut (Jelly -+ Water) & 9.2 & 3.68 \\
MC & Medium coconut (Water only) & 11.75 & 4.7 \\
DC & Dry coconut water (water only) & 13 & 5.2 \\
LBC & Local bottled commercial water & 9.2 & 3.68 \\
IBC & Brazilian bottled coconut water & 9.16 & 3.66 \\
IPC/F & Brazilian bottled coconut water (flavor) & 13.40 & 10.56 \\
MJ & Mango juice (300 g) & 56.55 & 18.85 \\
PJ & Passion fruit juice & 42.9 & 17.16 \\
- & Mean and (SE) & $18.59( \pm 5.32)$ & $7.58( \pm 1.86)$ \\
\hline
\end{tabular}

as oral rehydration salts (ORS) (Campbell-Falck et al., 2000).

Fresh coconut water is a refreshing drink but has limitations of timeliness and availability. Processing and pasteurization affects the quality, the delicate natural flavors and taste in addition to the nutrient value (Kuberski et al., 1979). It can be relatively deficient in sodium, chloride and bicarbonate, but has and adequate levels of potassium and glucose content (Campbell-Falck et al., 2000). It useful in rehydration of patients with Cholera caused by Vibrio cholerae (Bhattacharya, 2003); severe forms of gastroenteritis and mild diarrhoea (Adams and Bratt, 1992); Rotavirus infections; correct dehydration and acidosis, and promote intestinal healing (Germain-Nappert et al., 2000). However, the addition of table salt to the coconut water is suggested to compensate for the sodium and chloride deficiency (Kuberski et al., 1979).

The effectiveness of fresh young coconut for whole body rehydration and blood volume restoration was assessed and it revealed that body weight loss was regained, and that the rehydration index and restoration were not different (Saat et al., 2002). Further, there were no differences in serum $\mathrm{Na}^{+}, \mathrm{Cl}^{-}$, serum osmolality and net fluid balance, and it was significantly sweeter than mature coconuts. It caused less nausea with no stomach upset and was also easier to consume in a larger amounts. Pummer et al. (2001) assessed coconut water potential in maintaining hemostasis using thermo-blastography (TEG), and found that it did not differ from the effect caused by an identical volume of physiological saline. Ingestion of fresh young coconut water as a natural refreshing beverage could be used for whole body rehydration after exercise (Saat et al., 2002).

The availability of large quantities is needed in times of need in health disasters and long voyages. One way of ameliorating this situation is through a powdered form without affecting the quality and tastes. Freeze dried coconut water powder was observed to have a similar nutrient content and taste similar to fresh one
(Boonumma et al., 2014).This study sets out to evaluate freeze drying as a means to enhance the analyte balance, quality, taste, nutrient content of coconut water with added natural fruit flavours and its conversion into an isotonic oral rehydration fluid.

\section{MATERIALS AND METHODS}

The study was conducted at the Waterloo Research Campus of the University of Trinidad and Tobago during the period of 2013 to 2015. The process involved the conversion of fresh coconut water into crystals through freeze drying techniques and the addition of frozen tropical fruit crystals. The taste and analyte content of the ORS are evaluated by taste test and analytical methods according to the AOAC (Association of Official Analytical Chemists) procedure (AOAC, 2000).

The freshwater obtained from coconuts (Var. Malaysian Dwarf) were harvested in three stages of maturity viz. Dry (DC), medium (MC) and young (YC). The extra young coconuts (EYC) comprised both the coconut water and its soft jelly (SJ). The other sources of water were locally produced (LBC) or imported (Brazilian bottled coconut IBC) water. The two natural flavors used were produced from freshly frozen mango juice and pulp and passion fruit [PJ] all derived and extracted from organically produced fruits on the station. The water and flavors were frozen separately $\left(-30^{\circ} \mathrm{C}\right.$ for 48 h) for vacuum freeze-drying (VDF) in vacuum Labconco FreeZone ${ }^{\circledR}$ 2.5 Liter Freeze Dry System and vacuum pumped $\left(25^{\circ} \mathrm{C} / 5.0 \mathrm{~m}^{3} /\right.$ hour$)$. Samples were kept frozen $\left(-30^{\circ} \mathrm{C}\right)$ for taste-test comparisons with their re-constituted freeze-dried counterparts. All samples were subjected to a digestion process pre-mineral analysis on an Atomic Absorption Spectrophotometer and replicated three times. The elements analysed included Calcium, Iron, Magnesium, Phosphorus, Potassium, Sodium, Zinc, Copper and Manganese (Martin et al., 2014), in addition to the glucose and brix by refractotmer (ICUMSA 2013). All data were subject to statistical analysis using the software MINITAB package.

\section{RESULTS AND DISCUSSION}

The description of the varying maturity of the coconut water and the flavors used in the study before freezing $(\mathrm{g} / 250 \mathrm{ml})$ and VFD crystal yield $(\mathrm{g} / 100 \mathrm{ml})$ used in the preparation of the ORS are presented in Table 1. There 
Table 2. Brix (\%) and glucose (mg/L) at varying dilutions of rehydrations VFD crystal of coconut water and fruit juices.

\begin{tabular}{lccccccc}
\hline \multirow{2}{*}{$\begin{array}{l}\text { Treatment } \\
\text { codes }\end{array}$} & \multicolumn{2}{c}{ Brix (\%) } & Glucose (mg/L) & \multicolumn{4}{c}{ Glucose (mg/L) at dilutions } \\
\cline { 2 - 7 } & Fresh & VFD & Fresh & VFD (1:1) & $\mathbf{1 : 1 0}$ & $\mathbf{1 : 2 0}$ & $\mathbf{1 : 3 0}$ \\
\hline EYC & 4.0 & 2.0 & 301 & 309 & 90 & 27 & $<5$ \\
SJ/W & 5.5 & 3.2 & 575 & 483 & 208 & 128 & 39 \\
SJ/WJ & 5.2 & 5.2 & $>800$ & 714 & 600 & 114 & 97 \\
MC & 5.4 & 3.8 & $>600$ & 435 & 207 & 93 & 39 \\
DC & 5.2 & 4.5 & 290 & 34 & $<5$ & $<5$ & $<5$ \\
LBC & 3.8 & 3.4 & $>600$ & 415 & 256 & 159 & 126 \\
IBC & 6.5 & 4.0 & $>600$ & 493 & 101 & 21 & $<5$ \\
IPC/F & 6.1 & 6.0 & $>600$ & 310 & 47 & $<5$ & $<5$ \\
MJ & 16.0 & 3.2 & $>600$ & 288 & 101 & 50 & 25 \\
PJ & 13.3 & 5.3 & $>600$ & 424 & 272 & 182 & 153 \\
Mean (SE) & $7.1( \pm 1.30)$ & $4.1( \pm 0.38)$ & - & $390( \pm 55.6)$ & $170( \pm 37.6)$ & $76( \pm 21)$ & - \\
\hline
\end{tabular}

were variation in the yield in the different maturity of local and imported coconut water $(10.8 \pm 0.764)$ and crystal yields $(4.9 \pm 0.841)$. However, the yield in the fruit flavours were much higher with increased crystal yield. This maybe due to the higer concentration of soluble fibres and total soluble solids in the fruit juices.

There were no variations in the Brix (\%) amongst the fresh coconut water and VFD, but the fresh fruit juices were higher (Table 2). The Brix did not reduce after the water were converted to VFD compared to the fruit juices. In all cases except for EYC and DC, the glucose in the fresh state exceeded $500 \mathrm{mg} / \mathrm{L}$. In the VFD state at the $1: 1$ rehydration, all with the exception of $D C$ was on average $300 \mathrm{mg} / \mathrm{L}$ and more, and even at the 1:10 dilution, all the samples of coconut water except EYC were on average $100 \mathrm{mg} / \mathrm{L}$.

The mango and passion fruit crystals retained glucose values of over $100 \mathrm{mg} / \mathrm{L}$. This suggests that the addition of mango juice and PJ fruit crystals to the varying coconut water VFD's will not only enhance taste but give a wider variety of colors to choose from, but also improved the glucose content.

There were significant variations in the analyte balance between sources of coconut water, but less differences in the conversion from fresh to VFD. The $P$ concentration in all the samples varied between 1509 to $2191 \mathrm{mg} / \mathrm{L}$ and there were no reductions after conversion from fresh to VFD (Table 3). There was a similar trend for $\mathrm{K}$ which varied between 9.89 to $11.3 \mathrm{mg} / \mathrm{L}$. The $\mathrm{Ca}$ concentration was lower and varied between 160 to 499 (mg/L), and there were no changes except in the SJW by $50 \%$. No change was observe in the $\mathrm{Na}(0.0126$ to $0.008(\mathrm{mg} / \mathrm{L}))$, $\mathrm{Mg}(60.68$ to $65.21 \mathrm{mg} / \mathrm{L}), \mathrm{Cu}(<5 \mathrm{ppb}$ to $0.419 \mathrm{mg} / \mathrm{L})$ ), and $\mathrm{Fe}(<1.0 \mathrm{ppb}$ to $0.1436 \mathrm{mg} / \mathrm{L})$ and with small variations between samples. The $M n$ in the $D C$ increase by $30 \%$, and no change was observed in $\mathrm{Zn}$, except in IBC.

The ORS standards that was adopted by the Worlds Health Organization (WHO, 2012) has a sodium concentration of $75 \mathrm{mEq} / \mathrm{l}$, its glucose concentration was from 75 to $110 \mathrm{mmol} / \mathrm{l}$, and its total osmolarity was 245 $\mathrm{mOsm} / \mathrm{l}$, and also sodium (15-25 mEq/l), potassium (8$12 \mathrm{mmol} / \mathrm{l}$, citrate (50 to $80 \mathrm{mEq}$ ). Numerous studies have been undertaken to develop an "improved" ORS. The goal was a product that would be at least as safe and effective as standard ORS for preventing or treating dehydration from all types of diarrhoea but which, in addition, would reduce stool output or have other important clinical benefits. One approach has been used consistently in reducing the osmolarity of ORS solution to avoid possible adverse effects of hyper-tonicity on net fluid absorption. These were done by reducing the solution's glucose and salt $(\mathrm{NaCl})$ concentrations and as in this case improve by the VFD of flavored coconut water. Other commercial oral salts (Fife, 2014) have similar contents of $\mathrm{Na}(2.6 \mathrm{~g}), \mathrm{K}(1.5 \mathrm{~g})$, citrate 92.9 or 1020) and glucose (13.5).

De Sousa et al. (2005) found in their analysis of bottled coconut water that the macro- $(\mathrm{Ca}, \mathrm{Mg})$ and microconstituents ( $\mathrm{Mn}, \mathrm{Fe}, \mathrm{Zn}$ and $\mathrm{Cu}$ ) were in alignment of the Reference Daily Intakes for Minerals (RDI), and that nutritional contribution for $300 \mathrm{ml}$ of the beverage was more relevant for $\mathrm{Ca}(6 \%$ of the $\mathrm{RDI}), \mathrm{Mg}(8 \%$ of the $\mathrm{RDI})$ and $\mathrm{Mn}(56 \%$ of the RDI).

It was observed that coconut water had improved and controlled hypertension due to decreases in mean systolic and mean diastolic pressure were 24 and 15 $\mathrm{mmHg}$, respectively (Alleyne et al., 2005). Further, the water seemed to be a good source of dietary minerals, with potassium as the predominant one (Santoso et al., 1996). Regardless of the variety and stage of maturity of the fruit, it appeared to have a significant effect on the chemical composition (Jackson et al., 2004). Kalman et al. (2012) conducted a comparison of coconut water and a carbohydrate-electrolyte sport drink on measures of hydration and physical performance and found no differences between coconut for any measures of fluid retention. 
Table 3. Analytes of varying dilutions of rehydrations VFD crystal of coconut water and fruit juices.

\begin{tabular}{|c|c|c|c|c|c|c|c|c|c|c|c|c|c|c|c|c|c|c|}
\hline \multirow{2}{*}{$\begin{array}{l}\text { Analyte } \\
\begin{array}{l}\text { Treatment } \\
\text { codes }\end{array}\end{array}$} & \multicolumn{2}{|c|}{$P(\mathrm{mg} / \mathrm{L})$} & \multicolumn{2}{|c|}{$\mathrm{k}(\mathrm{mg} / \mathrm{L})$} & \multicolumn{2}{|c|}{$\mathrm{Ca}(\mathrm{mg} / \mathrm{L})$} & \multicolumn{2}{|c|}{$\mathrm{Na}(\mathrm{mg} / \mathrm{L})$} & \multicolumn{2}{|c|}{$M g(m g / L)$} & \multicolumn{2}{|c|}{$\mathrm{Fe}(\mathrm{mg} / \mathrm{L})$} & \multicolumn{2}{|c|}{$\mathrm{Zn}(\mathrm{mg} / \mathrm{L})$} & \multicolumn{2}{|c|}{$\mathrm{Mn}(\mathrm{mg} / \mathrm{L})$} & \multicolumn{2}{|c|}{$\mathrm{Cu}(\mathrm{mg} / \mathrm{L})$} \\
\hline & Fresh & VFD & Fresh & VFD & Fresh & VFD & Fresh & VFD & Fresh & VFD & Fresh & VFD & Fresh & VFD & Fresh & VFD & Fresh & VFD \\
\hline EYC & 1703 & 1684 & 10.2 & 10.96 & 494.3 & 393.4 & 0.010 & 0.009 & 61.91 & 61.45 & 0.014 & 0.006 & 0.64 & 0.51 & 4.79 & 4.04 & $<5 \mathrm{ppb}$ & $<5 \mathrm{ppb}$ \\
\hline SJ/W & 1509 & 1509 & 12.37 & 10.74 & 235.9 & 160 & 0.012 & 0.012 & 62.01 & 60.68 & $<1.0 \mathrm{ppb}$ & $<1.0 \mathrm{ppb}$ & 0.65 & 0.51 & 2.88 & 2.08 & $<5 \mathrm{ppb}$ & $<5 \mathrm{ppb}$ \\
\hline SJ/WJ & 1567 & 1556 & 10.11 & 11.23 & 218.6 & 228.7 & 0.011 & 0.008 & 63.2 & 62.73 & $<1.0 \mathrm{ppb}$ & $<1.0 \mathrm{ppb}$ & 0.73 & 0.70 & 2.891 & 2.59 & $<5 \mathrm{ppb}$ & $<5 \mathrm{ppb}$ \\
\hline $\mathrm{MC}$ & 1865 & 1897 & 11.31 & 9.25 & 293.5 & 259.6 & 0.008 & 0.009 & 63.81 & 63.47 & 0.047 & 0.04 & 0.78 & 0.70 & 5.108 & 4.44 & 0.031 & 0.04 \\
\hline $\mathrm{DC}$ & 2107 & 2191 & 10.93 & 10.22 & 172.1 & 166.8 & 0.011 & 0.011 & 64.64 & 65.21 & 0.045 & 0.07 & 0.42 & 0.30 & 52.97 & 80.2 & 0.11 & 0.11 \\
\hline LBC & 1683 & 1710 & 10.29 & 9.97 & 383.7 & 364.7 & 0.009 & 0.008 & 63.28 & 63.13 & 0.004 & 0.0002 & 0.52 & 0.48 & 3.016 & 2.842 & 0.050 & 0.012 \\
\hline $\mathrm{IBC}$ & 717.2 & 1346 & 11.18 & 13.36 & 144.5 & 130 & 0.5986 & 0.5953 & 69.13 & 68.53 & 0.407 & 0.33 & 1.644 & 0.4772 & 0.9356 & 0.9704 & 0.3462 & 0.2994 \\
\hline $\mathrm{IPC} / \mathrm{F}$ & 1647 & 1580 & 10.56 & 9.89 & 105 & 87.49 & 0.5933 & 0.5948 & 68.03 & 67.21 & 0.3032 & 0.3281 & 0.7365 & 0.6535 & 1.177 & 1.095 & 0.2443 & 0.2225 \\
\hline MJ & 1554 & 1608 & 11.96 & 11.8 & 511.4 & 499 & 0.006 & 0.0076 & 62.41 & 62.18 & 0.983 & 0.937 & 66.1 & 65.93 & 5.58 & 5.53 & 0.389 & 0.41 \\
\hline PJ & - & 1663 & 5.60 & 5.08 & 313.3 & 287 & 0.011 & 0.011 & 64.08 & 64.08 & 0.1436 & 0.132 & 51.73 & 49.99 & 1.46 & 1.47 & 0.160 & 0.20 \\
\hline
\end{tabular}

\section{Conclusion}

This study has shown that there were no changes in the analytes VFD coconut water, and had the same electrolyte balance as in fresh state. Moreover, the VFD extended the shelf life and storage capability of the product, and made it more available and easier to transport. Once stored properly, it is easy to dilute and administer The improvement in the taste made it more attractive to children who are sick and have loos of appetite as it is not bland as commercial rehydration fluids.

The recent epidemic of cholera has renewed interest in the use of coconut water as a rehydration fluid. Coconut water was analysed for a variety of constituents to assess its potential usefulness in the oral and parenteral rehydration of patients with cholera and other severe forms of gastroenteritis. Compared to oral rehydration fluids known to be effective in cholera, coconut water was found to have adequate potassium and glucose content, however was relatively deficient in sodium, chloride and bicarbonate (Roberts et al.,1990).

The addition of table salt to the coconut water is suggested to compensate for the sodium and chloride deficiency.

In areas of the world where coconuts are much, the advantages of sterility, availability and acceptability make coconut water theoretically feasible for the oral rehydration of patients with severe gastroenteritis when conventional fluids are unavailable.

\section{Conflict of interests}

The authors have not declared any conflict of interests.

\section{ACKNOWLEDGEMENTS}

The authors express their sincere appreciation to MsKarlene Fortune and the University of Trinidad and Tobago for their support towards this study.

\section{REFERENCES}

Adams W, Bratt DE (1992). Young coconut water for home rehydration in children with mild gastroenteritis. Trop. Geogr. Med. 44(1-2):149-153.

Alleyne T, Roache S, Thomas C, Shirley A (2005). The control of hypertension by use of coconut water and mauby: two tropical food drinks. West Indian Med. J. 54(1):3-8.

Bhattacharya SK (2003). An evaluation of current cholera treatment. Expert Opin. Pharm. 4(2):141-146.

Boonumma S, Chaisawadi S, Suwanyuen S (2014). Freeze dried coconut water powder processing for natural health drink. Acta. Hart 1023:91-94.

Campbell-Falck D, Thomas T, Falck TM, Tutuo N, Clem K (2000). The intravenous use of coconut water. Am. J. Emerg. Med. 18(1):108-111.

Damcevski K, Glover K, Green A, Haritos VS, Horne I, Singh SP, Zhou XR (2014). U.S. Patent No. 8,816,106. Washington, DC: U.S. Patent and Trademark Office.

De Sousa RA, Silva JC, Baccan N, Cadore S (2005). Determination of metals in bottled coconut water using an inductively coupled plasma optical emission spectrometer. J. Food Composition Anal. 18(5):399-408.

Fife B (2014). Coconut water: Dew from Heavens, coconut water for health and healing 2014. Available at https://www.google.tt/?gws_rd=cr,ssl\&ei=sbOGVfW9Ccazgg Sp1YLQBg\#q=Fife+B.+Coconut+water:+Dew+from+Heaven $\mathrm{s} \% 2 \mathrm{C}+$ coconut+water+for+health+and+healing $+200 \% 3 \mathrm{Bhtt}$ $\mathrm{p}: \% 2 \mathrm{~F} \% 2 \mathrm{Fwww}$.healthtruthrevealed 
Germain-Nappert DVM, Barrios JM, Zello G, Naylor J (2000). Nutrition Grand Rounds. Nutrition 1:80-87.

ICUMSA (2013). Methods Book", 2013 op. cit.; Specification and Standard SPS-3 Refractometry and Tables - Official; Tables A-F. Available at: www.icumsa.org/index.php?id=17

Jackson JC, Gordon A, Wizzard G, McCook K, Rolle R (2004). Changes in chemical composition of coconut (Cocosnucifera) water during maturation of the fruit. J. Sci. Food Agric. 84(9):1049-1052.

Kalman DS, Feldman S, Krieger DR, Bloomer RJ (2012). Comparison of coconut water and a carbohydrate-electrolyte sport drink on measures of hydration and physical performance in exercise-trained men. J. Int. Soc. Sports Nutr. 9(1):1.

Khan MN, Rehman M, Khan KW (2003). A study of the chemical compostion of Cocosnucifera water and its usefulness as rehydatron fluid. Pak. J. Bot. 35(5):925-930

Kuberski T, Roberts A, Linehan B, Bryden RN, Teburae M (1979). Coconut water as a rehydration fluid. N. Zealand Med. J. 90(641):98100.

Ma Z, Ge L, Lee AS, Yong JWH, Tan SN, Ong ES (2008). Simultaneous analysis of different classes of phytohormones in coconut (Cocos nucifera L.) water using high-performance liquid chromatography and liquid chromatography-tandem mass spectrometry after solid-phase extraction. Anal. Chem. Acta 610(2): 274-281.

Martin TD, Creed JT, Brockhoff CA (2014). Revision 2.8."Sample Preparation Procedure for Spectrochemical Determination of Total Recoverable Elements."Method 200.2- Aqueous Sample PreparationTotal Recoverable Analytes.Accessed September 16, 2014. https://www.envexp.com/download/techsupport/methods/200-2.pdf
Prakash L, Muhammed M (2008). Natural ingredients for anti-ageing skin care. Available http://www.cosmeticsdesign.com/Formulation-Science/Sabinsa-scoconut-ingredient-gets-patent-protection

Pummer S, Heil P, Maleck W, Petroianu G (2001). Influence of coconut water on hemostasis. Am. J. Emerg. Med. 19(4):287-289.

Saat M, Singh R, Sirisinghe RG, Nawawi M (2002). Rehydration after exercise with fresh young coconut water, carbohydrate-electrolyte beverage and plain water. J. Physiol. Anthropol. Appl. human Sci. 21(2):93-104.

Santoso U, Kubo K, Ota T, Tadokoro T, Maekawa A (1996). Nutrient composition of kopyor coconuts (Cocos nucifera L.). Food Chem. 57(2):299-304.

World Health Organization (2012). Medicines and Health Products Information Portal WHO Drug Information 2012. 16(2).

Yong JW, Ge L, Ng YF, Tan SN (2009). The chemical composition and biological properties of coconut (Cocos nucifera L.) water. Molecules 14(12):5144-5164. 